\title{
Potential for biogas production from the anaerobic digestion of chicken droppings in Morocco
}

\author{
Ouahid Elasri ${ }^{1} \cdot$ Mohamed El amin Afilal ${ }^{1}$
}

Received: 23 June 2015/Accepted: 5 May 2016/Published online: 24 May 2016

(c) The Author(s) 2016. This article is published with open access at Springerlink.com

\begin{abstract}
Purpose The chicken droppings can have a negative impact on the environment and public health. In this work, we are interested in treating this waste by anaerobic digestion and we estimate the national potential of green energy produced by anaerobic digestion and map the areas that need digesters to improve national poultry farming.

Methods The anaerobic digestion of this waste is performed in three steps. In the first step, the chicken droppings are placed in a laboratory digester without pretreatment. In the second step, the droppings are placed in an industrial digester without pretreatment. In the third step, a methanogenic inoculum is incubated with the chicken droppings in a batch digester. The biogas production is measured by manometer, and the composition of this biogas is analyzed by gas chromatography.

Results The chicken droppings without pretreatment generated a small amount of biogas (11.24 and $20 \mathrm{~m}^{3}$ for one ton of waste fresh) in the laboratory and in the prototype digester. After pretreatment (heating and grinding), this waste produced a large quantity of biogas, on the order $230,58 \mathrm{ml} / \mathrm{gCOD}$, equivalent to $64.4 \mathrm{~m}^{3}$ for one ton of fresh waste, with $60.2 \%$ methane, $38.8 \%$ carbon dioxide and $0 \%$ hydrogen. This biogas production has a lower heating value of $385 \mathrm{kWh}$ for one ton of chicken droppings. Based on these results, our country has high potential for green energy (200 GWh) by transforming the droppings of broilers by anaerobic digestion.
\end{abstract}

Ouahid Elasri

elasriouahid@yahoo.fr

1 Biological Plants and Microorganisms Laboratory, BP 524, 60000 Oujda, Morocco, Mohammed First University, 60000 Oujda, Morocco
Conclusion In Morocco, the installation of biogas digesters in poultry units is an effective technique for this industry, because this waste is a potential energy source.

Keywords Chicken droppings - Anaerobic digestion · Green energy · Biogas · Pretreatment · Inoculums

\section{Introduction}

The generation of organic waste in Morocco continues to increase each year (Afilal et al. 2007). Moroccan poultry is one of the fastest growing industrial activities. Morocco is the first country classified for breeding broilers in northern Africa, with 195 million heads produced in 2013 (FAOSTAT 2015). This production represents $43.1 \%$ of the livestock in the Maghrebian region, because chicken is the most consumed meat by Moroccan $(52 \%$ of all meat consumed in 2014) (Agriculture du Maghreb 2010; FAOSTAT 2015). The national poultry sector has undergone significant development; the poultry meat production increased from 510,000 tons in 2010 to 649,000 tons in 2013 to cover $100 \%$ of the demand for poultry meat on the Moroccan market (Ministère de l'Agriculture 2012).

This important development of the Moroccan poultry activities resulted in a large production of organic residual waste. Morocco produces more than 519,000 tons of broiler droppings per year, of which more than $95 \%$ is directly used as fertilizer for agriculture without pretreatment (Elasri and Afilal Elamin 2014). This organic waste can have a negative impact on the environment and public health, because the droppings contain high contents of nitrogen $(4.48 \%)$, total organic carbon $(16.5 \%)$ and pathogenic bacteria, mainly Staphylococci and 
Enterobacteriaceae $\left(114.10^{8}\right.$ and $\left.154.10^{6} \mathrm{CFU} / \mathrm{g}\right)$ (Arifin et al. 2006; Elasri and Afilal Elamin 2014; Karwowska 2005; Plewa and Lonc 2011). These quantities of bacteria, carbon and nitrogen can be lost through lixiviation or runoff and can be found in groundwater and surface water, causing diseases or epidemics (Chen and Jiang 2014; Ganoulis 2012; Kostadinova 2013; Stefanova et al. 2012). Outdoor landfills produce greenhouse gases (emission factor is $0.023 \mathrm{~kg} \mathrm{head}{ }^{-1}$ year $^{-1}$ ) (Jun et al. 2002; Kostadinova et al. 2014). Morocco is under strong energy constraints, as illustrated by an energy deficit that has worsened over time (approximately $83 \%$ in 1980 and increased to $97 \%$ in 2009) (Afilal et al. 2013).

In addition to these problems, with the progressive production of droppings of chickens and the energy deficit, it is necessary to develop technology that combines the management, valorization and production of green energy starting from these wastes to improve the energy balance of this livestock. Among the current technologies, methanization is gaining more importance in Morocco and around the world. Methanization is based on the degradation of various organic wastes in hermetically closed bioreactors (Niu et al. 2015). These wastes are partially converted by microorganisms to biogas (Budzianowski 2016).

In this work, we are interested in:

1. Treating this waste by anaerobic digestion and achieving the maximum production of biogas with a high percentage of methane for energy use.

2. Estimating the national potential of green energy produced by the anaerobic digestion of broiler droppings and maps the areas that require the installation of digesters to improve national poultry farming.

\section{Materials and methods}

\section{Substrate}

The substrate studied in this paper is the droppings of chickens taken from a poultry unit (Fig. 1a). Droppings were collected after cleaning the hen-houses of intensive breeding unit broiler located a few kilometres from the city of Oujda in Morocco (Fig. 1b). The sampling location is at the following coordinates $\left(34^{\circ} 41^{\prime} 43.7^{\prime \prime} \mathrm{N}^{\circ} 50^{\prime} 35.01^{\prime \prime} \mathrm{W}\right)$. The determination of the type of waste is difficult, because the classification of waste is highly variable (Buenrostro et al. 2001); it depends on the criteria chosen by the authors (Castelli et al. 2012). After a synthesis of these criteria, the broiler droppings are qualified as organic waste, putrescible, residual and rapidly biodegradable (Elasri and Afilal Elamin 2014).

\section{Chemical analyses}

In this article, we have identified several chemical characteristics for Moroccan chicken droppings, including, total solids (TS), fresh matter (FM), volatile solids (VS) and chemical oxygen demand (COD), but for the inoculum, we determined COD (Table 1).

\section{Dry matter and volatile dry matter}

The determination of total solids is performed according to the standard protocol, which consists of drying the wet sample at $105{ }^{\circ} \mathrm{C}$ to a constant weight (over 24 h) (APHA 1999).

$\mathrm{TS}=\left(M_{1} \times 100\right) / M_{0}$

TS: Total solids (g TS/gFM).

MF: Fresh matter (g).

$M_{0}$ : Initial weight of the sample before drying $(\mathrm{g})$.

$M_{1}$ : Final weight of the sample after drying $(\mathrm{g})$.

The determination of volatile matter (or volatile solids) is also a gravimetric method based on the weight loss of the dry sample (the sample from determining TS) in a muffle furnace at $550{ }^{\circ} \mathrm{C}$ for $6 \mathrm{~h}$ (APHA 2005). The remaining material is considered mineral material (MM), and the material that disappeared is organic matter $(\mathrm{OM})$.

$\mathrm{VS}=\left(M_{1}-M_{2}\right) \times 100 / M_{1}$

VS: volatile Matter (g VS/g TS).

$M_{1}$ : Mass of dry substrate $(\mathrm{g})$.

$M_{2}$ : Mass of substrate calcined at $550{ }^{\circ} \mathrm{C}(\mathrm{g})$.

\section{Chemical oxygen demand (COD)}

This characteristic is determined using the chemical oxygen demand corresponding to the amount of oxygen required for complete oxidation of organic matter and a mineral in a sample. The COD gives the quality of the substrate before placing it into the digester. COD was determined for the inoculum and droppings. The inoculum used in this article is in the liquid state. We determined the COD of the inoculum by kit (Spectroquant Merck Cod cell test 114,555 , measuring range $500-10,000 \mathrm{mg} / \mathrm{L}$ ) (Perimenis et al. 2015).

The chicken droppings are in the solid state; therefore, they are analyzed using the Belgian standard, which comprises the oxidizing agent in excess and potassium dichromate $\left(\mathrm{K}_{2} \mathrm{Cr}_{2} \mathrm{O}_{7}\right)$. The reaction occurs in an acid medium $\left(\mathrm{H}_{2} \mathrm{SO} 4\right)$ upon heating at reflux in the presence of a catalyst $\left(\mathrm{Ag}_{2} \mathrm{SO}_{4}\right)$ and a complexion agent of chloride ions $\left(\mathrm{HgSO}_{4}\right)$. In this paper, we titrated the residual potassium dichromate (back titration) with a solution of sulfate of iron and ammonium $\left(\mathrm{Fe}\left(\mathrm{NH}_{4}\right)_{2}\left(\mathrm{SO}_{4}\right)_{2}\right)$ called Mohr salt. We 

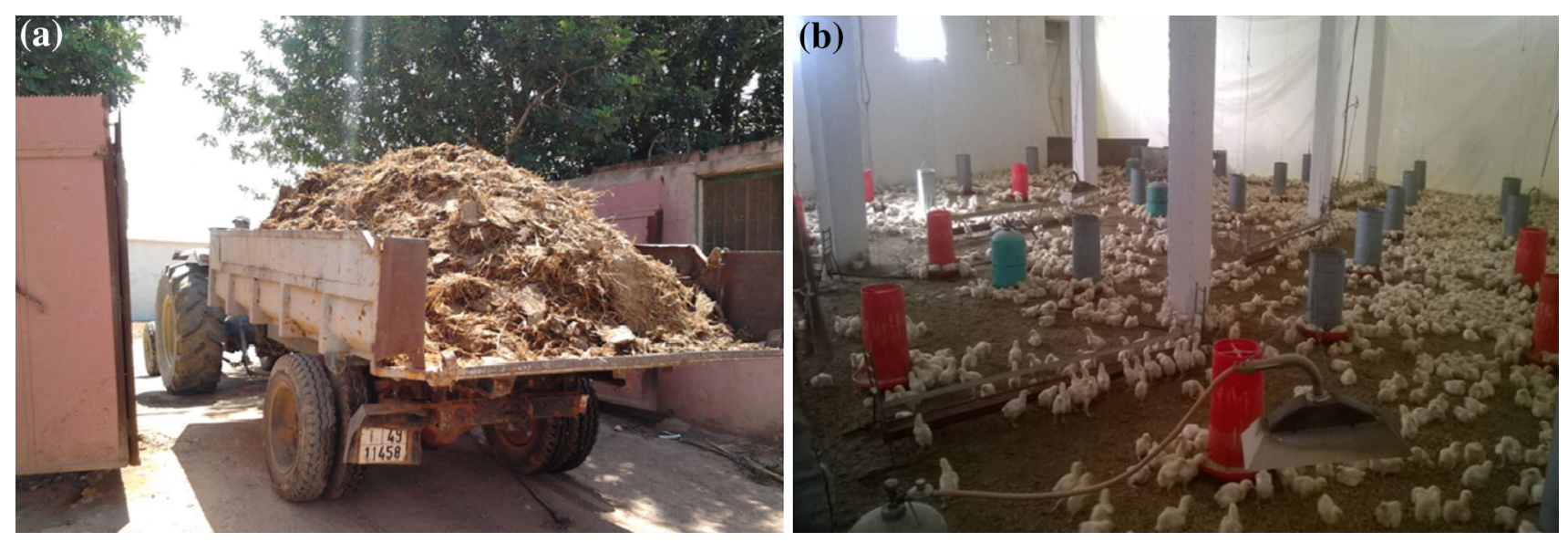

Fig. 1 a Chicken droppings collected in a truck; b Hen-houses of intensive breeding

used ferroin as an indicator, because it changed colour from blue-green to red-brown (APHA 1999). The COD is expressed as grams of oxygen per gram of sample.

\section{Test of the anaerobic digestion of droppings without pretreatment}

This test is performed on two levels: at the laboratory scale, all digesters used in this test are 5 litre hermetically closed bottles with waste at $10 \%$, that is to say, $10 \mathrm{~g}$ of dropping in $100 \mathrm{ml}$ of tap water. We followed the production of biogas for 40 days (Afilal et al. 2014).

On the industrial scale, we filled a 1000 litre capacity prototype (a horizontal digester) with $260 \mathrm{~kg}$ of droppings dissolved in 640 litres ( $8 \%$ TS), and we followed the biogas production for 40 days. We adjusted the temperature of the digester to $35^{\circ} \mathrm{C}$. The biogas product is measured every day by a flow meter. In the two tests, the waste does not undergo any pretreatment.

\section{Test of the anaerobic digestion of droppings with pretreatment and addition of inoculum}

\section{Origin and activation of inoculum}

The inoculum used in this article is an anaerobic sludge collected at the treatment plant Chastre/Mont-Saint-Guibert, Belgium. This inoculum was maintained at $35^{\circ} \mathrm{C}$ under anaerobic conditions. The inoculum is preserved in a $20 \mathrm{~L}$ reactor sealed with a silicone plug. The activation of the inoculum is performed with the sludge collected from the same sewage plant. The addition of activation substrate to the inoculums was in the ratio of $3 \mathrm{~g} \mathrm{COD} / 7 \mathrm{~g} \mathrm{COD}$, i.e., $30 \%$ of the total chemical oxygen demand (COD) of the digester of inoculum (20 L) (Perimenis et al. 2015). In practice, $1.8 \mathrm{~L}$ of the sludge (substrate of activation) was added to digester (119 COD) of inoculum. Then, we put the digester in a room at $35^{\circ} \mathrm{C}$ for 10 days. Before testing the digestibility, all organic matter must be exhausted, and the bacteria must be activated.

\section{Test of biodigestibility}

The droppings of chickens underwent two pretreatment steps: heating at $105^{\circ} \mathrm{C}$ for $24 \mathrm{~h}$, this thermal pretreatment also leads to pathogen removal, improves dewatering performance and reduces viscosity of the digestate, with subsequent enhancement of digestate handling (Ariunbaatar et al. 2014; Bougrier et al. 2007) and the second pretreatment is a very fine grinding with a mill (IKA A11 Basic) (Carlsson et al. 2012). The incubation obeys the $1 / 5$ ratio for testing potential methanogenics, i.e., each digester has to contain a quantity of droppings (1.5 g COD) in the inoculum (7.5 g COD), so that the inoculum is not limited, but the organic matter accompanying the inoculum does not contribute to the production of biogas with respect to the substrate to be tested (Van Aarle et al. 2015). We performed six digestions: three controls (inoculum only)

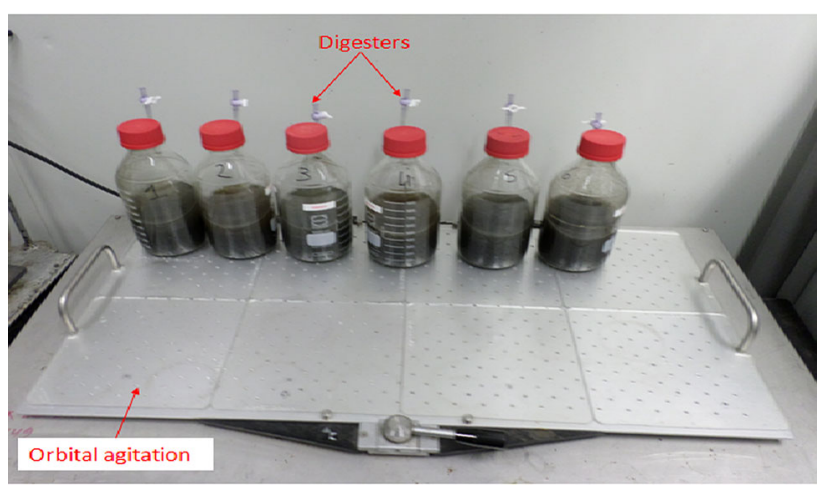

Fig. 2 Six digesters under continuous orbital agitation (120 rpm) 
and three tests (inoculum with droppings) (Fig. 2). The initial $\mathrm{pH}$ for the six digesters is $7.1 \pm 0.41$ for the three tests and $6.8 \pm 0.2$ for the inoculums; these values show that the $\mathrm{pH}$ is favorable and it is in areas of optimization of anaerobic digestion (Chen et al. 2008); therefore, the $\mathrm{pH}$ of the batch does not require an adjustment. The filling of the six reactors is performed on a balance. The gas spaces of the six reactors are subjected to nitrogen flushing to remove the oxygen present in the reactor and to stabilize the anaerobic conditions. We closed all reactors. The six reactors were incubated in a warm room at $35 \pm 1{ }^{\circ} \mathrm{C}$ under continuous orbital agitation (120 rpm) (Chun et al. 2015; Vindis et al. 2009). The anaerobic digestion continues for 40 days in batch mode.

\section{Measurement and analysis of biogas production}

The daily biogas production can be measured using a digital manometer with a three-way valve at the top of the connector. This manometer measures the pressure in each reactor. This pressure is measured manually by connecting the manometer previously calibrated to the two-way valve of the reactor (Fig. 3a).
The measured pressure value is used to calculate the volume of biogas produced under the standard conditions using the following equation (Estevez et al. 2012):

$\Delta V_{2}=\frac{\Delta P_{1} \times V_{1} \times T_{2}}{T_{1} \times P_{2}}$

where $\Delta V_{2}=$ Volume of biogas produced between two measurements and corrected to the standard conditions (ml).

$\Delta P_{1}=$ Pressure difference between two measurements in the reactor $(\mathrm{Pa})$.

$V_{1}=$ Volume of gas headspace of the reactor ( $\left.\mathrm{ml}\right)$.

$T_{1}=$ Temperature in the reactor $(308.15 \mathrm{~K})$.

$T_{2}=$ Standard condition of temperature $(273.15 \mathrm{~K})$.

$P_{2}=$ Atmospheric pressure at standard conditions (101,325 Pa).

The quantity of biogas generated by the substrate is obtained by subtracting the amount of biogas produced in the control reactor, i.e., inoculum alone.

As soon as the measurement of biogas production is complete, we proceed in collecting and analyzing the composition of biogas. The biogas collected by the polycarbonate syringe of $50 \mathrm{ml}$ (Terumo Luer lock), it was
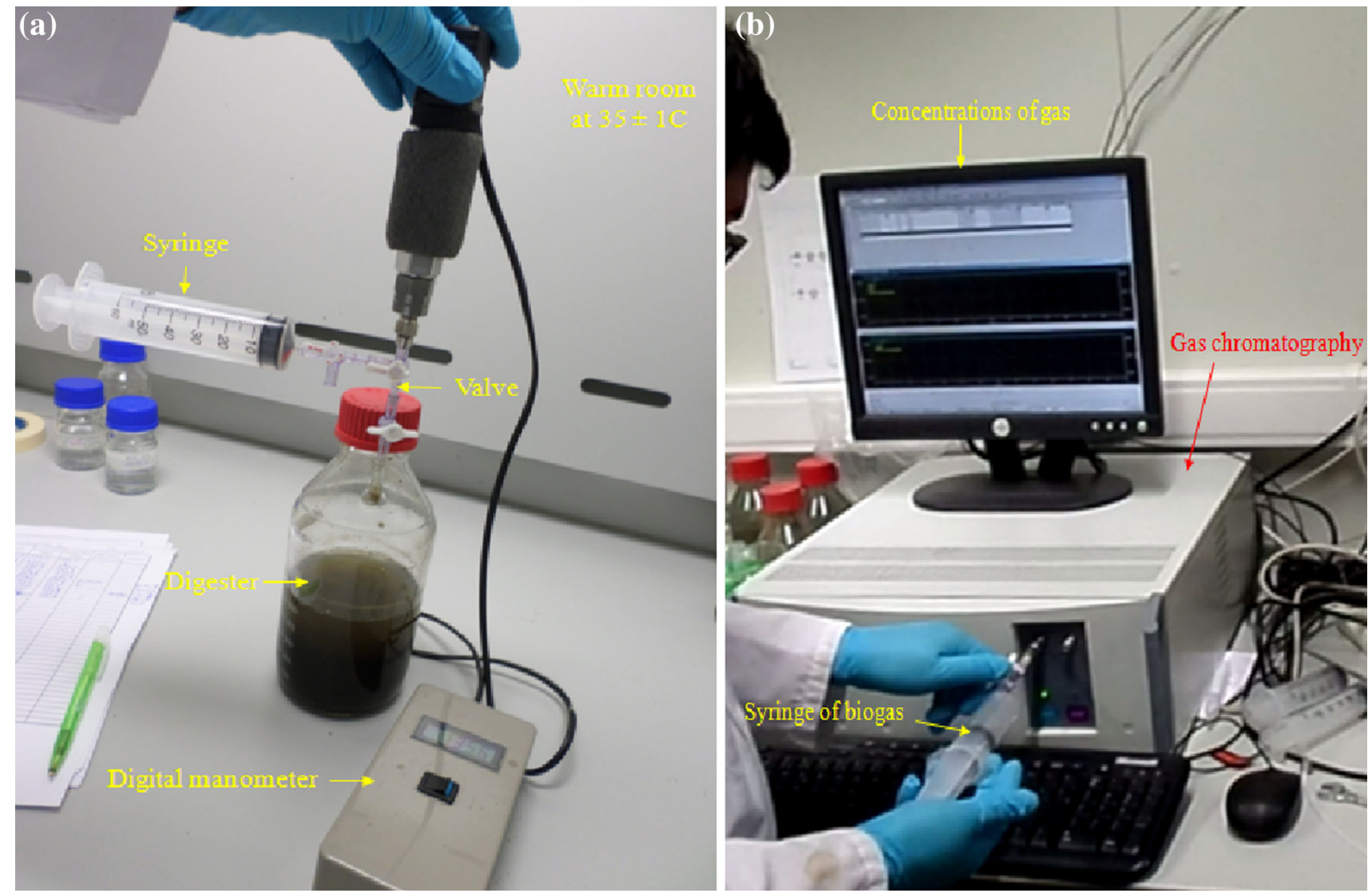

Fig. 3 Measurement and analysis of biogas production. a Measurement of pressure. b Analysis of composition of biogas produced 
immediately injected into the gas chromatography (GC) (Saady and Massé 2016) (Fig. 3b).

The gas chromatography used in this work is the type (Compact GC-TCD); it determines automatically three types of gases $\left(\mathrm{CO}_{2}, \mathrm{CH}_{4}\right.$ and $\left.\mathrm{H}_{2}\right)$ in biogas production. The Compact GC-TCD is composed of two separate channels operating in parallel and each provided with a $25 \mu \mathrm{l}$ injection loop and an independent TCD detector. These channels are called the "Front Channel" and "Back Channel". The injection of a gas is done using a polypropylene syringe fitted with a valve; the gas enters an injection circuit via the injector (sample in) and passes through the two injections loops and spring (sample out).

\section{Results and discussion}

\section{The characterization of the substrate before anaerobic digestion}

The chemical characteristics are shown in Table 2. One gram of COD is equal to $1 \mathrm{~g}$ of VS; therefore, the organic matter present in the droppings is all biodegradable (Hamilton 2012). These three chemical characteristics of the chicken droppings show that the droppings contain a large organic biodegradable fraction, which leads to the production of large quantities of biogas. This result is confirmed by the production of a large quantity of biogas (230.58 $\mathrm{ml} / \mathrm{g} \mathrm{COD)}$.

Table 1 Nomenclature

\begin{tabular}{ll}
\hline $\mathrm{CFU}$ & Colony-forming unit \\
$\mathrm{CH}_{4}$ & Methane \\
$\mathrm{CO}_{2}$ & Carbon dioxide \\
$\mathrm{COD}$ & Chemical oxygen demand \\
$\mathrm{FM}$ & Fresh matter \\
$\mathrm{GC}$ & Gas chromatography \\
$\mathrm{H}_{2}$ & Hydrogen \\
$\mathrm{N}$ & North \\
$\mathrm{TCD}$ & Thermal conductivity detector \\
$\mathrm{TS}$ & Total solids \\
VS & Volatile solids \\
W & West \\
\hline
\end{tabular}

Table 2 Composition of chicken droppings

\begin{tabular}{lcl}
\hline Chemical characteristics & Quantity & Unit \\
\hline COD & $1.01 \pm 0.01$ & g/g VS \\
TS & $32 \pm 4$ & g/100 g FM \\
VS & $28 \pm 0.2$ & g/100 g FM \\
\hline
\end{tabular}

Test of the anaerobic digestion of droppings without pretreatment

The first test produced a small amount of biogas (11.24 $\left.\pm 1.2 \mathrm{~m}^{3} / \mathrm{T} \mathrm{MF}\right)$ compared to other studies that considered an optimal amount within the range $61-112 \mathrm{~m}^{3} /$ T MF (Afilal et al. 2014; Brodeur et al. 2008) (Table 3). At the industrial scale, the prototype produces a large amount of biogas $\left(20 \mathrm{~m}^{3} / \mathrm{T} \mathrm{MF}\right)$ compared to that obtained at the laboratory scale for several reasons: the use of an optimal concentration (8 \% TS) (Budiyono et al. 2010; Salam et al. 2015; Zennaki-Bensouda et al. 1996); the significant volume of the digester $(1000 \mathrm{~L})$ can contain a large quantity of waste $(250 \mathrm{~kg})$ and thus have a high probability of having methanogen bacteria in each batch (Nopharatana et al. 2007); the design of the prototype allows for rapidly reaching anaerobic conditions by effective sealing and reduced gas headspace; and, finally, the addition of an inoculum increased the speed of the process (GonzálezFernández and García-Encina 2009).

\section{Test of the anaerobic digestion of droppings pretreated with inoculum}

\section{Analysis of the quantity and composition of biogas production}

We follow the production of biogas in the six digesters (three controls and three tests) for $1195 \mathrm{~h}$ (equivalent to 49 days). The anaerobic digestion of chicken droppings begins in the early hours of incubation (not time latency) and generates a high quantity of biogas of $230.58 \pm 4.36 \mathrm{ml} / \mathrm{g}$ COD substrate during the 49 days of incubation. One gram of COD is equal to $1 \mathrm{~g}$ of $\mathrm{VS}$, and consequently, this the quantity of biogas is equivalent to $64.4 \pm 4.36 \mathrm{~m}^{3} / \mathrm{TMF}$, i.e., one ton of the pretreated droppings produced $64.4 \mathrm{~m}^{3}$ of biogas. Comparing these results with the previous results shows that this quantity is very high $\left(7.66,11.24 \mathrm{~m}^{3} / \mathrm{t} \mathrm{FM}\right.$ and other researchers that $112 \mathrm{~m}^{3} / \mathrm{t} \mathrm{FM}$ ) (Afilal et al. 2014; CRAAQ 2008; Fischer 2007). This significant quantity of biogas is the result of several conditions: an efficient inoculum capable of converting the organic matter present in the studied waste, the use of a closed room at $35{ }^{\circ} \mathrm{C}$ (Yadvika et al. 2004), continuous agitation during $1194 \mathrm{~h}$ of incubation, and the pretreatment of the droppings increased surface area provides better contact between substrate and anaerobic bacteria (Carrère et al. 2010; Val del Río et al. 2011). The droppings contain less efficient methanogenic bacteria flora compared to the inoculum used in this article. Therefore, we need to avoid the anaerobic digestion of this waste by its own bacteria.

We analyzed the composition of biogas produced during the incubation ( $1195 \mathrm{~h}$, equivalent to 49 days) by gas 
Table 3 Comparison of the biogas potential of three tests
Potential of biogas $\left(\mathrm{m}^{3} / \mathrm{T} \mathrm{FM}\right)$

$11.24 \pm 1.2$

$20 \pm 1.5$

$64.4 \pm 4.36$

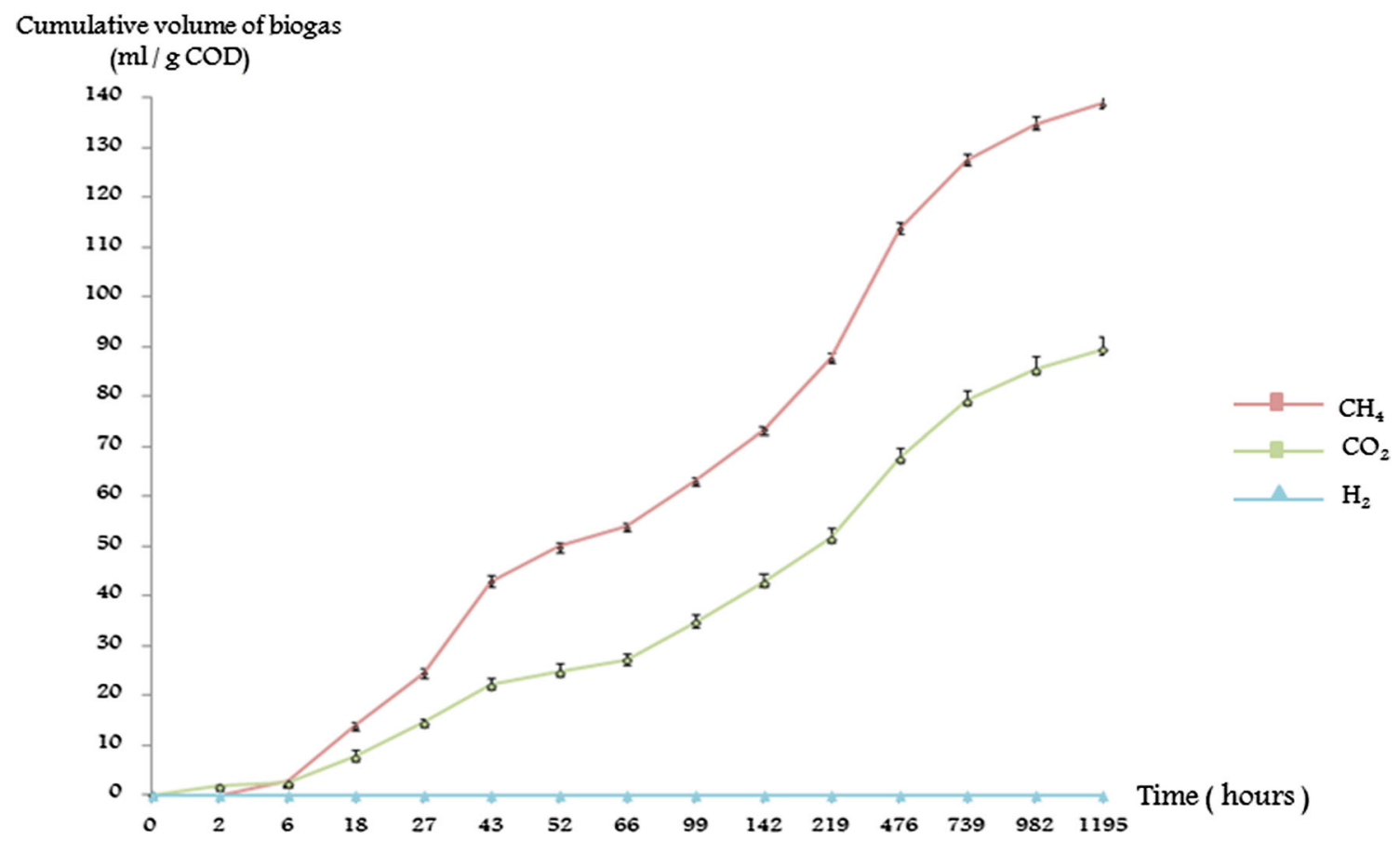

Fig. 4 Kinetics of gases produced by chicken droppings

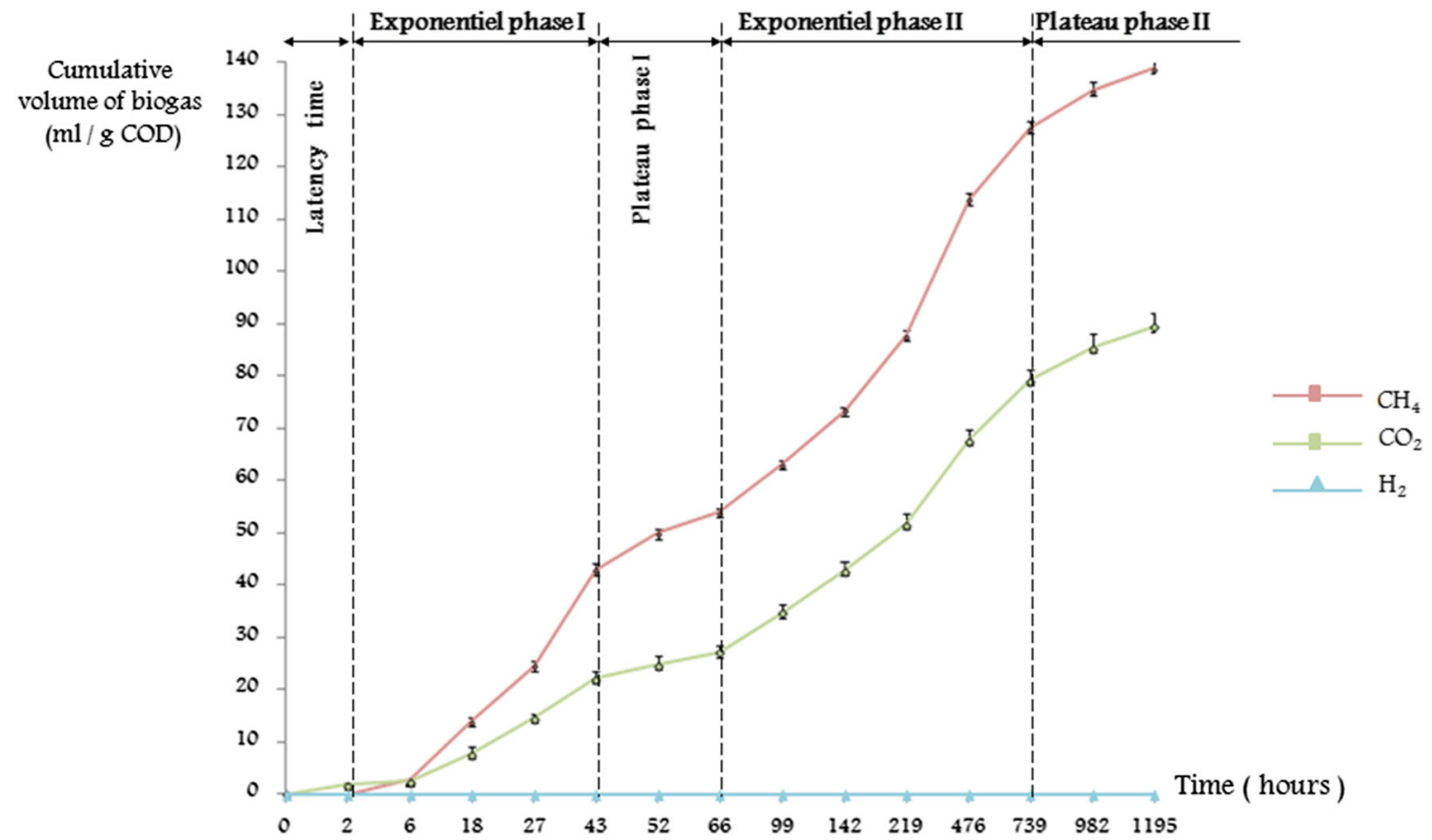

Fig. 5 Different phases of methane production by the Belgian inoculum 


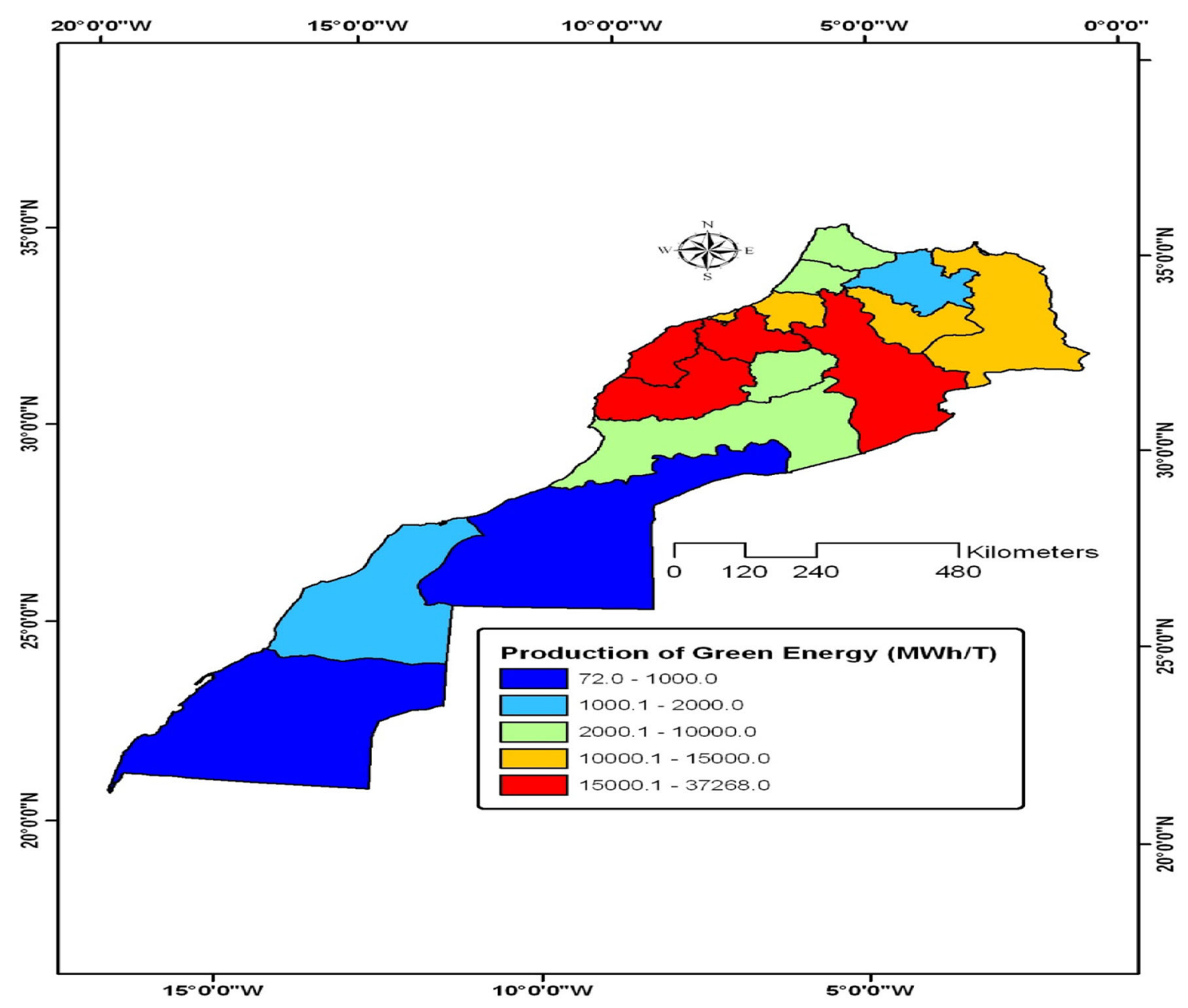

Fig. 6 Map of distribution of green energy produced by the anaerobic digestion of chicken droppings in Morocco

chromatography and obtained the kinetics of the constituent gases (Fig. 4). The biogas produced has only two gases: methane $\left(\mathrm{CH}_{4}\right)$ and carbon dioxide $\left(\mathrm{CO}_{2}\right)$. Hydrogen is absent during the incubation, indicating that it is not stored in the headspace of the digester.

From an industrial and economic point of view, the anaerobic digestion of droppings from chickens in a digester allows for storing all of the biogas that is produced. The anaerobic digestion of droppings from chickens produced biogas with a minimum of $60.2 \% \pm 2.33$ methane and $38.8 \% \pm 2.71$ carbon dioxide. Therefore, the biogas presents a lower heating value of $5.98 \pm 2.33 \mathrm{kWh} / \mathrm{m}^{3}$.

\section{Kinetics of methane production}

The kinetics of the production of methane shows a biphasic exponential pace, with a single latency time for methane. According to the speed of methane production, this curve can be cut into five phases (Fig. 5):
- The latency phase is $2 \mathrm{~h}$, resulting from the use of an organic complex chemical composition, which needs the intervention of bacteria in the first three stages of anaerobic digestion (hydrolysis, acidogenesis and acetogenesis) to degrade and convert the substrates available for the methanogenic stage (acetate, $\mathrm{CO}_{2}$ and $\mathrm{H}_{2}$ ). This time $(2 \mathrm{~h})$ is very short in other works, which have very high latency time of up to a few days (Afilal et al. 2014; Budiyono et al. 2010). Therefore, this short latency time showed that the inoculum used in this study includes a range of bacteria for hydrolysis, with high-performance acidogenesis and acetogenesis, which rapidly degrades droppings and makes the substrates available for the production of methane. Thus, this short period may be utilized by methanogenic bacteria that are acclimatizing to environmental conditions and new substrates (Nopharatana et al. 2007).

- After the latency time, the production of methane gradually began as exponential phase I. After $2 \mathrm{~h}$ of 
incubation, the production of methane is accelerated with a high speed of $1.04 \mathrm{ml} / \mathrm{g}$ COD.h. This phase corresponds to the availability of simple and biodegradable substrates for methane transformation. This result shows that methanogens in the inoculum require little time for their appearance (less than $2 \mathrm{~h}$ ), which is less than the standard of 3-7 h. Therefore, this inoculum has interesting properties.

- Plateau phase I, which require a $23 \mathrm{~h}$ incubation, corresponds to the low production of methane with a speed on the order of $0.48 \mathrm{ml} / \mathrm{g}$ COD.h. During this phase, there is a decrease of easily biodegradable organic material present in the chicken droppings (Alfa et al. 2014).

- Exponential phase II lasts $673 \mathrm{~h}$ with the low production of methane of $73.27 \mathrm{ml} / \mathrm{g}$ COD with low production speed of $0.10 \mathrm{ml} / \mathrm{g}$ COD.h. Methane produced during this phase transformation is from the organic fraction of the complex, which is difficult to microbially degrade and takes more time to degrade, producing a small quantity over a long time period.

- The plateau phase (II). During this phase, there is negligible production of methane with negligible speed of $0.02 \mathrm{ml} / \mathrm{g}$ COD.h due to the absence of substrate for digestion. Therefore, this phase represents the exhaustion of all biodegradable material present in the droppings.

The kinetics of methane production shows an acclimatization phase and very short bearing phase, but the exponential phases have fast speeds. Consequently, the conversion of organic waste material to methane is very fast when using this Belgian inoculum.

\section{Estimation of deposit of green energy}

Based on these results, we can to map the potential of green energy produced by the anaerobic digestion of chicken droppings in every region of Morocco and localize the regions that need to install digesters. This production $\left(64.4 \mathrm{~m}^{3} / \mathrm{TMF}\right.$ with $\left.5.98 \mathrm{kWh} / \mathrm{m}^{3}\right)$ is multiplied by the amount of waste produced in each region (Kumaran et al. 2016). Morocco has a high potential for green energy (200 GWh) from transforming the droppings of broilers by anaerobic digestion (Fig. 6).

The region Chaouia-Ouardigha has the highest potential green energy production of 37,268 MWh. Four regions (Chaouia-Ouardigha, Tensift-Al Haouz Marrakech, Meknes-Tafilalet and Doukkala-Abda) represent $55 \%$ of the whole national potential. The installation of biogas units for chicken droppings should be focused on western Morocco. In Fig. 2, the areas in red and orange are the principal regions of energy production by methanization. These regions are the target regions for installation of methanization units for chicken waste.

\section{Conclusion}

The anaerobic digestion of Moroccan chicken waste by inoculum sludge from the waste water treatment plant Chaste/Mont-Saint-Guibert in Belgium generates a high quantity of biogas of $230.58 \mathrm{ml} / \mathrm{g}$ COD substrate. The quantity produced is composed of $60.2 \%$ methane, $38.8 \%$ carbon dioxide and $0 \%$ hydrogen; therefore, it presents a lower heating value of $5.9 \mathrm{kWh} / \mathrm{m}^{3}$.

Based on this work, the daily development of the Moroccan poultry keeps getting better. This development is accompanied by the progressive production of broiler chicken droppings, which can cause several types of pollution. This waste is an energy source that renews every day. The treatment of this waste by anaerobic digestion has shown that these substrates can produce a large amount of biogas $\left(64.4 \mathrm{~m}^{3} / \mathrm{TMF}\right)$, which can be converted to green energy (385 kWh/t FM). The methanization of wastes requires pretreatment by heat, grinding and the addition of an inoculum before introducing the waste into a digester.

Acknowledgments We deeply thank Thomas Nicolay and Patrick Gerin from the Catholic University of Leuven, Laboratory of Biological Engineering, Southern Cross Building 2 in 1348 Louvain-laNeuve, Belgium.

\section{Compliance with ethical standards}

Conflict of interest The authors declare that they have no competing interests. We do not have any financial competing interests, because we have no financial support. We want to release this work to the whole world.

Author's contribution Elasri Ouahid made substantial contributions to the conception, design, analysis and interpretation of data; he has been involved in drafting the manuscript and revising it critically for important intellectual content. Finally, he has given final approval of the version to be published. (AB, MT, ES and FG). Afilal Mohamed Elamin has been involved in drafting the manuscript and revising it critically for important intellectual content (FG).

Open Access This article is distributed under the terms of the Creative Commons Attribution 4.0 International License (http://crea tivecommons.org/licenses/by/4.0/), which permits unrestricted use, distribution, and reproduction in any medium, provided you give appropriate credit to the original author(s) and the source, provide a link to the Creative Commons license, and indicate if changes were made.

\section{References}

Afilal ME, Filali-Meknassi Y, Auriol M (2007) Valorisation des déchets organiques par production de biogaz: l'énergie de 
biomasse., in: Les énergies renouvelables au Maroc-Le débat est lané. Rabat Maroc 112-120

Afilal ME, Belkhadir N, Daoudi H, Elasri O (2013) Fermentation méthanique des différents substrats organiques (Methanic fermentation of different organic substrates). J Mater Env Sci $11-16$

Afilal ME, Elasri O, Merzak Z (2014) Caractérisations des déchets organiques et évaluation du potentiel Biogaz (Organic waste characterization and evaluation of its potential biogas). J Mater Env, Sci 5

Agriculture du Maghreb (2010) Filière avicole dynamisme permanent. 94-96

Alfa IM, Dahunsi SO, Iorhemen OT, Okafor CC, Ajayi SA (2014) Comparative evaluation of biogas production from Poultry droppings, Cow dung and Lemon grass. Bioresour Technol 157:270-277. doi:10.1016/j.biortech.2014.01.108

APHA (1999) Standard methods for the examination of water and wastewater. American Public Health Association and Water Environment Federation, Washington DC

APHA (2005) Standard methods for the examination of water and wastewater. American Public Health Association and Water Environment Federation

Arifin B, Bono A, Janaun J (2006) The transformation of chicken manure into mineralized organic fertilizer. J Sustain Sci Manag $1: 58-63$

Ariunbaatar J, Panico A, Esposito G, Pirozzi F, Lens PNL (2014) Pretreatment methods to enhance anaerobic digestion of organic solid waste. Appl Energy 123:143-156. doi:10.1016/j.apenergy. 2014.02.035

Bougrier C, Delgenès JP, Carrère H (2007) Impacts of thermal pretreatments on the semi-continuous anaerobic digestion of waste activated sludge. Biochem Eng J 34:20-27. doi:10.1016/j.bej. 2006.11.013

Brodeur C, Crowley D, Desmeules X, Pigeon S, St-Arnaud R-M (2008) La biométhanisation à la ferme

Budiyono Widiasa, Johari IN, Sunarso S (2010) The influence of total solid contents on biogas yield from cattle manure using rumen fluid inoculum. Energy Res. J 1:6-11

Budzianowski WM (2016) A review of potential innovations for production, conditioning and utilization of biogas with multiplecriteria assessment. Renew Sustain Energy Rev 54:1148-1171. doi:10.1016/j.rser.2015.10.054

Buenrostro O, Bocco G, Cram S (2001) Classification of sources of municipal solid wastes in developing countries. Resour Conserv Recycl 32:29-41. doi:10.1016/S0921-3449(00)00094-X

Carlsson M, Lagerkvist A, Morgan-Sagastume F (2012) The effects of substrate pre-treatment on anaerobic digestion systems: a review. Waste Manag 32:1634-1650. doi:10.1016/j.wasman. 2012.04.016

Carrère H, Dumas C, Battimelli A, Batstone DJ, Delgenès JP, Steyer JP, Ferrer I (2010) Pretreatment methods to improve sludge anaerobic degradability: a review. J Hazard Mater 183:1-15. doi:10.1016/j.jhazmat.2010.06.129

Castelli F, Lentini V, Maugeri M (2012) Static and dynamic waste characterization, in: Proc., 5th European Geosynthetics Congress, EUROGEO. pp. 105-110

Chen Z, Jiang X (2014) Microbiological Safety of Chicken Litter or Chicken Litter-Based Organic Fertilizers: a Review. Agriculture 4:1-29. doi:10.3390/agriculture4010001

Chen Y, Cheng JJ, Creamer KS (2008) Inhibition of anaerobic digestion process: a review. Bioresour Technol 99:4044-4064. doi:10.1016/j.biortech.2007.01.057

Chun CW, Zainol NFM, Jamaludin N (2015) Optimization of biogas production from poultry manure wastewater in $250 \mathrm{ml}$ flasks. J Teknol 75:275-285
CRAAQ (2008) La biométhanisation à la ferm. Cent. Réf. En Agric. Agroaliment, Qué 5

Elasri O, Afilal Elamin M (2014) Etude de risque de contamination des eaux marocaines par les fientes de poulet de chair. Int J Innov Appl Stud 7:593-601

Estevez MM, Linjordet R, Morken J (2012) Effects of steam explosion and co-digestion in the methane production from Salix by mesophilic batch assays. Bioresour Technol 104:749-756. doi:10.1016/j.biortech.2011.11.017

FAOSTAT (2015) Food and Agriculture Organization of the United Nations. Statistics Division, compare data, production live animals, Morocco, Algeria, Egypt, Libya, Mauritania and Tunisia, Chickens, Stocks

Fischer T (2007) Expérience allemande: politique et appresentissage technologique, in: Pesentation on CRAAQ, Conference in Montreal

Ganoulis J (2012) Risk analysis of wastewater reuse in agriculture. Int J Recycl Org Waste Agric 1:1-9

González-Fernández C, García-Encina PA (2009) Impact of substrate to inoculum ratio in anaerobic digestion of swine slurry. Biomass Bioenergy 33:1065-1069. doi:10.1016/j.biombioe.2009.03.008

Hamilton DW (2012) Anaerobic digestion of animal manures: methane production potential of waste materials, cooperative extension, Service edn. Oklahoma State University, Division of Agricultural Sciences and Natural Resources, USA

Jun P, Gibbs M, Gaffney K (2002) CH4 and N2O emissions from livestock manure. Good practice guidance and uncertainty management in national greenhouse gas inventories. IPCC by the Institue for Global Environmental Strategies. Penman J, Kruger D, Galbally I, Hayama, Japan, pp 321-381

Karwowska E (2005) Microbiological air contamination in farming environment. Pol J Environ Stud 14:445-449

Kostadinova G (2013) Sanitary hygienic assessment of drinking water from underground source at a pig farm. Agric Sci Technol 5:448-454

Kostadinova G, Petkov G, Denev S, Miteva C, Stefanova R, Penev T (2014) Microbial pollution of manure, litter, air and soil in a poultry farm. Bulg J Agric Sci 20:56-65

Kumaran P, Hephzibah D, Sivasankari R, Saifuddin N, Shamsuddin AH (2016) A review on industrial scale anaerobic digestion systems deployment in Malaysia: opportunities and challenges. Renew Sustain Energy Rev 56:929-940. doi:10.1016/j.rser.2015. 11.069

Ministère de l'Agriculture, et de la Pêche Maritime, Ministère de l'Agriculture (2012) Situation de l'Agriculture Marocaine, in: Produits de Terroir: Une Stratégie D'action Le Long de La Chaine de Valeurs. Maroc, pp. 169-170

Niu Q, Takemura Y, Kubota K, Li Y-Y (2015) Comparing mesophilic and thermophilic anaerobic digestion of chicken manure: microbial community dynamics and process resilience. Waste Manag 43:114-122. doi:10.1016/j.wasman.2015.05.012

Nopharatana A, Pullammanappallil PC, Clarke WP (2007) Kinetics and dynamic modelling of batch anaerobic digestion of municipal solid waste in a stirred reactor. Waste Manag 27:595-603

Perimenis A, van Aarle IM, Nicolay T, Jacquet N, Meyer L, Richel A, Gerin PA (2015) Metabolic profile of mixed culture acidogenic fermentation of lignocellulosic residues and the effect of upstream substrate fractionation by steam explosion. Biomass Convers. Biorefinery 6:25-37. doi:10.1007/s13399-015-0164-8

Plewa K, Lonc E (2011) Analysis of airborne contamination with bacteria and moulds in poultry farming: a case stady. Pol J Environ Stud 20:725-731

Saady NMC, Massé DI (2016) Feasibility and performance of highrate psychrophilic dry anaerobic digestion of high solids content 
dairy manure. J Recycl Org Waste Agric, Int. doi:10.1007/ s40093-016-0115-9

Salam B, Biswas S, Rabbi MS (2015) Biogas from mesophilic anaerobic digestion of cow dung using silica gel as catalyst. Procedia Eng. 105:652-657. doi:10.1016/j.proeng.2015.05.044

Stefanova R, Kostadinova G, Georgieva N (2012) Water quality assessment from own source at poultry farm located in rural region in South Bulgaria. Agric Sci Technol 4:143-147

Val del Río A, Morales N, Isanta E, Mosquera-Corral A, Campos JL, Steyer JP, Carrère H (2011) Thermal pre-treatment of aerobic granular sludge: impact on anaerobic biodegradability. Water Res 45:6011-6020. doi:10.1016/j.watres.2011.08.050

Van Aarle IM, Perimenis A, Lima-Ramos J, de Hults E, George IF, Gerin PA (2015) Mixed inoculum origin and lignocellulosic substrate type both influence the production of volatile fatty acids during acidogenic fermentation. Biochem Eng $\mathbf{J}$ 103:242-249. doi:10.1016/j.bej.2015.07.016

Vindis P, Mursec B, Janzekovic M, Cus F (2009) The impact of mesophilic and thermophilic anaerobic digestion on biogas production. J Achiev Mater Manuf Eng 36:192-198

Yadvika Santosh, Sreekrishnan TR, Kohli S, Rana V (2004) Enhancement of biogas production from solid substrates using different techniques-a review. Bioresour Technol 95:1-10. doi:10.1016/j.biortech.2004.02.010

Zennaki-Bensouda Z, Zald A, Lamini H, Aubineau M, Boulif M (1996) Fermentation méthanique des déchets de bovins: étude du temps de rétention hydraulique, de la température et de la concentration en 